\title{
Microheterogeneity of acute-phase glycoproteins in patients with pulmonary sarcoidosis
}

\author{
P. Hrycaj*, K. Wurm**, P. Mennet*, W. Müller*
}

Microheterogeneity of acute-phase glycoproteins in patients with pulmonary sarcoidosis. P. Hrycaj, K. Wurm, P. Mennet, W. Müller. @ CERS Journals Ltd 1996.

ABSTRACT: This study was designed to investigate qualitative changes in the carbohydrate side-chains of two acute-phase glycoproteins, $\alpha_{1}$-acid glycoprotein (AGP) and $\alpha_{1}$-antichymotrypsin (ACT), in 37 patients with pulmonary sarcoidosis.

The glycosylation profile of AGP and ACT was studied using affinity immunoelectrophoresis with the lectin concanavalin A $(\operatorname{con} A)$. Serum concentration of soluble receptor for interleukin-2 (sIL-2R) and activity of serum angiotensin converting enzyme (ACE) were measured by specific enzyme-linked immunosorbent assay (ELISA) and enzyme kinetic assay, respectively. Rocket immunoelectrophoresis and nephelometric assay were used to determine serum concentration of AGP, ACT and C-reactive protein (CRP).

In 11 patients with active disease, a decreased reactivity of AGP with conA was found as compared with controls $(n=44)$ and patients with nonactive sarcoidosis $(n=26)$. A similar tendency was seen with ACT. In the same group, increased concentrations of serum AGP and higher levels of SIL-2R were detected compared with patients with nonactive sarcoidosis. In the entire sarcoidosis group, there was a negative correlation between ACE activity and AGP and ACT affinity for conA ( $r=$ -0.6358 , and $r=-0.5019$, respectively) and a positive correlation with sIL-2R level $(\mathbf{r}=\mathbf{0 . 8 2 4 1})$. In nine patients with elevated concentrations of serum CRP, no differences were found in disease activity and glycosylation profile of AGP and ACT when compared to patients with normal serum CRP.

The results suggest that in active pulmonary sarcoidosis changes in the glycosylation pattern of acute-phase glycoproteins exist, which are similar in trend and magnitude to those found in other chronic inflammatory diseases. The synthesis and glycosylation of acute-phase proteins in pulmonary sarcoidosis are probably regulated independently.

Eur Respir J., 1996, 9, 313-318.
*Hochrhein Institute for Research and Prevention of Rheumatic Diseases, Bad Säckingen (Germany)/Rheinfelden (Switzerland). **Clinic Sonnenhof, Höchenschwand, Germany.

\section{Correspondence: P. Hrycaj}

Dept of Immunology and Rheumatology Karol Marcinkowski University School of Medicine

Szkolna 8/12

60-967 Poznan

Poland

Keywords: Acute-phase proteins glycosylation sarcoidosis

serum angiotensin converting enzyme soluble interleukin-2 receptor

Received: February 281995

Accepted after revision October 121995
Most acute-phase proteins, with only few exceptions, carry N-glycosidically linked oligosaccharides. The most characteristic acute-phase glycoprotein, $\alpha_{1}$-acid glycoprotein (AGP), consists of a single polypeptide chain with five $\alpha$-mannose-containing heteroglycan side-chains coupled to five asparagin molecules $[1,2]$. Another typical member of this group, $\alpha_{1}$-antichymotrypsin (ACT) possesses three carbohydrate side-chains. It has been shown that the carbohydrate moieties of acute-phase glycoproteins may vary significantly in their structure - a property which has been termed "microheterogeneity". Some of them have two branches attached to the common pentasaccharide core unit (biantennary heteroglycans), the other have three or four core-linked terminal chains (tri- and tetra-antennary carbohydrates, respectively) $[3,4]$.

To study the microheterogeneity of AGP and other acute-phase glycoproteins, affinity immunoelectrophoresis with the lectin concanavalin $\mathrm{A}(\operatorname{con} \mathrm{A})$ as a ligand has been used [5]. The presence of either two $\alpha$-linked nonreducing terminals or $\alpha$-linked 2-O-substituted mannose residues with unmodified C-3, C-4 and C-6 hydroxyl groups in heteroglycan chains of particular glycoproteins is required for binding to conA [6]. Only biantennary carbohydrates of AGP react with the lectin and, therefore, various microheterogeneous forms of AGP containing different number of biantennary heteroglycans differ in their reactivity with conA [4]. Difference in affinity for the lectin results in the different mobility of particular AGP glycoforms in the conA-containing agarose gel during electrophoresis [7].

Inflammatory states are usually associated with changes in the glycosylation profile of acute-phase proteins. It has been demonstrated that there is an increased concentration of the conA-reactive microheterogeneous forms of acute-phase glycoproteins in patients with acute inflammations, such as acute bacterial infections, tissue necrosis or burns [8-10]. Conversely, a shift in the population of acute-phase glycoproteins towards those with a higher content of conA-nonreactive tri- and tetra-antennary 
carbohydrates has been shown in the sera of patients with chronic inflammatory diseases (e.g. chronic bacterial infections, rheumatoid arthritis, ankylosing spondylitis) $[8$, $11,12]$.

Little is known of the acute-phase response in patients with pulmonary sarcoidosis. In a recent work, it was suggested that serum concentration of acute-phase proteins is usually normal or only slightly elevated in most patients with sarcoidosis and does not relate to disease stage or activity [13]. There is no report dealing with the glycosylation profile of acute-phase glycoproteins in patients with sarcoidosis.

In this work, we used affinity immunoelectrophoresis to study the microheterogeneity of serum AGP and ACT in patients with pulmonary sarcoidosis. The main question that we addressed was whether there are any changes in the glycosylation profile of these proteins. Additionally, we looked for an eventual relationship between the glycosylation profile of acute-phase glycoproteins and two markers of disease activity, serum activity of angiotensin converting enzyme (ACE) and serum concentration of soluble receptor for interleukin-2 (sIL-2R) [14-16].

\section{Patients and methods}

\section{Patients}

Thirty seven patients with pulmonary sarcoidosis were studied. All of them were in-patients of sarcoidosis clinic in Höchenschwand, Germany. No patients with extrapulmonary manifestations were included, to ensure homogeneity of the study group. The characteristics of the study group regarding sex, smoking status, age, and disease duration have been shown in table 1. In all cases, the diagnosis of sarcoidosis was established according to clinical and laboratory findings, and was confirmed by biopsy. Diseases different from sarcoidosis but similar in their clinical appearance (e.g. tuberculosis) were excluded. Chest radiographic images were made to assess the stage of the disease. At entry, there were 21 patients with stage I, 10 patients with stage II, and 6 patients with stage III disease. Chest radiograms were then repeated two times (after 6 and 12 months) to confirm an eventual disease progression. For purpose of the study,

Table 1. - Characteristics of the patients with pulmonary sarcoidosis and of the controls

\begin{tabular}{lcc}
\hline & $\begin{array}{c}\text { Patients } \\
(\mathrm{n}=37)\end{array}$ & $\begin{array}{c}\text { Controls } \\
(\mathrm{n}=44)\end{array}$ \\
\hline $\begin{array}{l}\text { Sex M/F } \\
\text { Smokers/nonsmokers } \\
\text { Males }\end{array}$ & $19 / 18$ & $19 / 25$ \\
$\quad \begin{array}{l}\text { Females } \\
\text { Age* yrs }\end{array}$ & $5 / 14$ & $7 / 12$ \\
Males & $3 / 15$ & $7 / 18$ \\
& & \\
Females & 48 & 50 \\
& $(30-68)$ & $(23-80)$ \\
Disease duration* yrs & 51 & 45 \\
& $(27-69)$ & $(23-84)$ \\
\hline
\end{tabular}

patients were considered to have an "active" sarcoidosis if progression of pulmonary changes was seen on subsequent chest radiograms, and an increased activity of ACE was found in serum specimens. Blood samples were taken from all patients on the day they were included in the study, and two serum specimens for each patient were stored frozen at $-90^{\circ} \mathrm{C}$. No patients were receiving glucocorticoids for at least 3 months before and during the study.

\section{Controls}

The control group $(n=44)$ consisted of 20 healthy individuals recruited from clinic staff and 24 patients with osteoarthritis. Since osteoarthritis is not associated with changes in the glycosylation pattern of acute-phase proteins, the patients with osteoarthritis were included as additional control of the affinity immunoelectrophoresis. See table 1 for data on sex, smoking status and age in the control group. The sex and age distribution in the control group did not differ from the sex and age distribution in the patient group. Also, both groups were similar regarding smoking behaviour. As expected, no significant differences were found in AGP and ACT affinity for conA, and serum concentration of AGP, ACT and C-reactive protein (CRP) between healthy controls and patients with osteoarthritis.

\section{Affinity immunoelectrophoresis}

Affinity immunoelectrophoresis with conA was carried out as described by BøG-HANSEN [5], with some minor modifications. Briefly, conA (Sigma type 4, C2010 Sigma, St. Louis, USA) at a concentration of 40 $\mathrm{mmol} \cdot \mathrm{L}^{-1}$ was incorporated into the first dimension agarose gel and electrophoresis was carried out for $60 \mathrm{~min}$ at $10 \mathrm{~V} \cdot \mathrm{cm}^{-1}$. Gel strips were then transferred onto the second dimension plate and the gel adjacent to the first dimension gel was poured out. It contained anti-AGP (or anti-ACT) antibodies (Dakopatts), and 7.5\% of methyl$\alpha$-D-mannopyranoside (Sigma) to solubilize the conAglycoprotein complexes. After electrophoresis (16-18 h, $1.5 \mathrm{~V} \cdot \mathrm{cm}^{-1}$ ) gel was pressed, dried and stained using Coomassie brilliant blue R-250 (Sigma). The areas enclosed by the precipitates representing microheterogeneous variants of AGP and ACT (fig. 1) were measured planimetrically. The results were expressed as reactivity coefficients (AGP-RC and ACT-RC, respectively) calculated according to the formula: total area under the peaks of the conA-reactive variants (1-3) divided by the area enclosed by the peak representing the conA-nonreactive variant $(0)$.

\section{Determination of serum AGP and ACT concentrations}

Serum AGP and ACT concentrations were determined by rocket immunoelectrophoresis according to LAURELL [17]. Serum protein calibrator (Dako, code No. X908, lot 010) was used to construct the standard curve. The concentrations were calculated using linear regression and expressed in $\mathrm{g} \cdot \mathrm{L}^{-1}$. 
a)

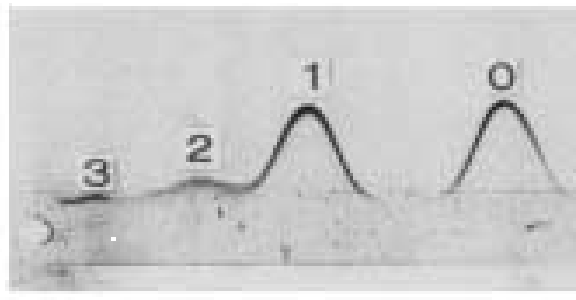

b)

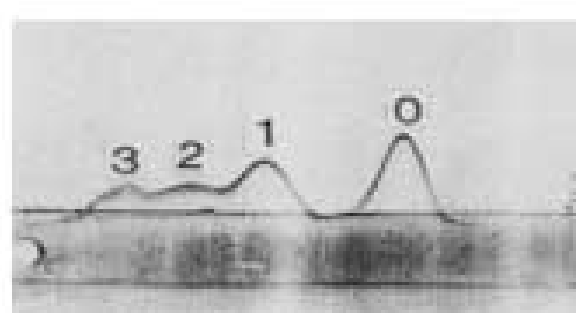

Fig. 1. - Normal glycosylation pattern of: a) $\alpha_{1}$-acid glycoprotein (AGP); and b) $\alpha_{1}$-antichymotrypsin (ACT). Affinity immunoelectrophoresis with conA was carried out as described in text. 0: conA nonreactive variant; $1-3$ : conA reactive variants. conA: concanavalin $\mathrm{A}$.

\section{Determination of serum concentration of $C R P$}

Serum CRP levels were measured using a routine nephelometric method. The results were expressed in $\mathrm{mg} \cdot \mathrm{L}^{-1}$.

\section{Determination of serum activity of $A C E$}

ACE activity was determined using a routine automated enzyme kinetic assay. As a substrate, N-(3-[2furyl]acryloyl)-L-phenylalanyl-glycylglycine (FAPGG) was used, at concentration of $1.0 \mathrm{mmol} \cdot \mathrm{L}^{-1}$. The reaction was carried out in borate buffer $\left(80 \mathrm{mmol} \cdot \mathrm{L}^{-1}\right.$, $\mathrm{pH}=8.2$ ) at $37^{\circ} \mathrm{C}$. Absorbance of the product was measured at $345 \mathrm{~nm}$. The linearity range of the assay extended to $180 \mathrm{U} \cdot \mathrm{L}^{-1}$ (25\% of substrate hydrolysis). Results were expressed in $\mathrm{U} \cdot \mathrm{L}^{-1}$. Intra- and interassay variability did not exceed $5 \%$.

\section{Determination of serum concentration of $s I L-2 R$}

Serum level of sIL-2R was measured using commercial enzyme-linked immunosorbent assay (ELISA) kit (DAKO, code No. K004, lot No. 062). All samples were examined in duplicate and the sIL-2R concentration was calculated using the standard curve constructed from known sIL-2R levels, and corresponding optical densities obtained for standards provided with the kit. The coefficients of variation $(\mathrm{CV} \%)$ did not exceed $10 \%$. The results were expressed in $\mathrm{U} \cdot \mathrm{mL}^{-1}$.

\section{Statistics}

To analyse the data, descriptive statistics and standard nonparametric and parametric tests were used. Medians were compared using Mann-Whitney U-test. Chi-squared or Fisher's exact test were applied to compare frequencies of particular findings in the subsets of patients. Relationships between variables were studied using analysis of variance and regression. When applicable, 95\% confidence intervals were assumed.

\section{Results}

The entire sarcoidosis group did not differ significantly from the controls in AGP-RC (1.20 vs 1.20), ACT-RC (3.71 vs 3.76) and concentration of AGP (1.27 vs 1.10 $\left.\mathrm{g} \cdot \mathrm{L}^{-1}\right)$, ACT (0.48 vs $0.49 \mathrm{~g} \cdot \mathrm{L}^{-1}$, and CRP (2.9 vs 2.25 $\left.\mathrm{mg} \cdot \mathrm{L}^{-1}\right)$, all values are medians. In 11 patients with active disease, however, median values of AGP-RC were decreased ( $<<0.01$ ) (fig. 2). A similar (but not significant) tendency was seen with ACT-RC (fig. 3). The patients

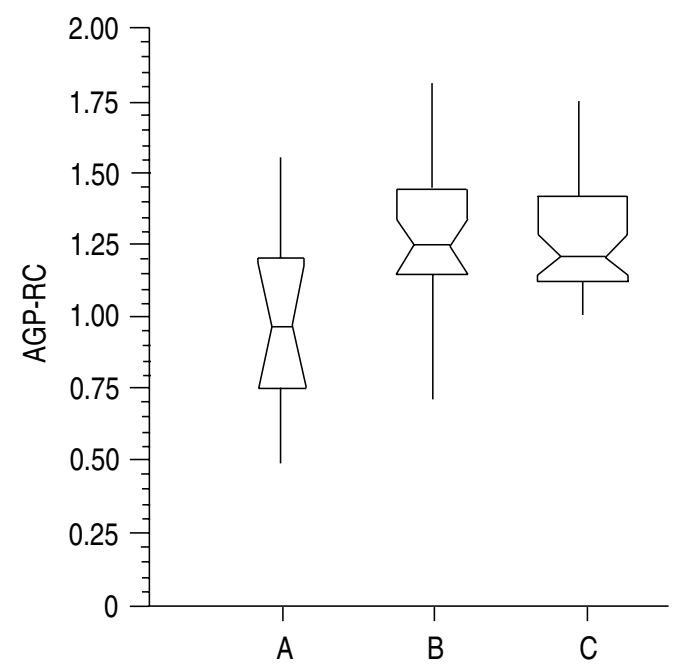

Fig. 2. - Notched box-and-whiskers plots showing statistical summaries of $\alpha_{1}$-acid glycoprotein reactivity coefficient (AGP-RC) in patients with active sarcoidosis (A), nonactive sarcoidosis (B), and in controls (C). The box covers the middle $50 \%$ of the data values, between the lower and upper quartile. The notches indicate the 95\% confidence limits. The "whiskers" extend out to the extremes (minimum and maximum values) that are within 1.5 times the interquartile range, whilst the central line represents median.

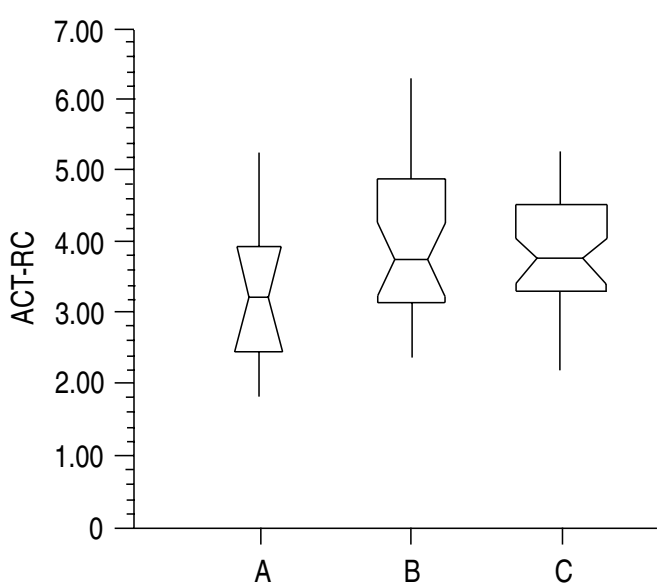

Fig. 3. - Notched box-and-whiskers plots showing statistical summaries of $\alpha_{1}$-antichymotrypsin reactivity coefficient (ACT-RC) in patients with active sarcoidosis (A), nonactive sarcoidosis (B), and in controls $(\mathrm{C})$. The box covers the middle $50 \%$ of the data values, between the lower and upper quartile. The notches indicate the $95 \%$ confidence limits. The "whiskers" extend out to the extremes (minimum and maximum values) that are within 1.5 times the interquartile range, whilst the central line represents median. 
Table 2. - AGP-RC, ACT-RC, AGP, ACT, CRP, ACE, and SIL-2R in patients with pulmonary sarcoidosis in relation to the disease stage*

\begin{tabular}{lrlllllll}
\hline & $\begin{array}{c}\text { Pt } \\
\mathrm{n}\end{array}$ & AGP-RC & ACT-RC & $\begin{array}{c}\text { AGP } \\
\mathrm{g} \cdot \mathrm{L}^{-1}\end{array}$ & $\begin{array}{c}\text { ACT } \\
\mathrm{g} \cdot \mathrm{L}^{-1}\end{array}$ & $\begin{array}{c}\mathrm{CRP} \\
\mathrm{mg} \cdot \mathrm{L}^{-1}\end{array}$ & $\begin{array}{c}\mathrm{ACE} \\
\mathrm{U} \cdot \mathrm{L}^{-1}\end{array}$ & $\begin{array}{c}\mathrm{sIL}-2 \mathrm{R} \\
\mathrm{U} \cdot \mathrm{mL}^{-1}\end{array}$ \\
\hline Stage 1 & 21 & $1.21 \pm 0.06$ & $3.73 \pm 0.22$ & $1.39 \pm 0.19$ & $0.48 \pm 0.04$ & $3.3 \pm 1.0$ & $38.5 \pm 6.8$ & $375 \pm 195$ \\
Stage 2 & 10 & $1.18 \pm 0.12$ & $4.61 \pm 0.39$ & $1.07 \pm 0.08$ & $0.47 \pm 0.05$ & $2.0 \pm 1.3$ & $31.0 \pm 16.0$ & $405 \pm 102$ \\
Stage 3 & 6 & $1.15 \pm 0.15$ & $3.27 \pm 0.48$ & $1.22 \pm 0.23$ & $0.37 \pm 0.05$ & $2.0 \pm 0.9$ & $37.2 \pm 13.1$ & $365 \pm 168$ \\
\hline
\end{tabular}

Values are presented as median \pm SEM. AGP-RC: AGP reactivity coefficient; ACT-RC: ACT reactivity coefficient; AGP: $\alpha_{1}$-acid glycoprotein; ACT: $\alpha_{1}$-antichymotrypsin; CRP: C-reactive protein; ACE: angiotensin-converting enzyme; sIL-2R: serum interleukin2 receptor. *: all differences were statistically nonsignificant.

with active disease also had elevated serum AGP (1.96 $\left.\mathrm{g} \cdot \mathrm{L}^{-1} ; \mathrm{p}<0.02\right)$ but their median ACT $\left(0.55 \mathrm{~g} \cdot \mathrm{L}^{-1}\right)$ and CRP $\left(3.3 \mathrm{mg} \cdot \mathrm{L}^{-1}\right)$ levels did not differ from those in the control group. When compared with patients with low disease activity $(n=26)$, those with active sarcoidosis had lower values of AGP-RC (p<0.01) (fig. 2), increased concentrations of serum AGP (1.96 vs $\left.1.12 \mathrm{~g} \cdot \mathrm{L}^{-1} ; \mathrm{p}<0.05\right)$, and raised sIL-2R levels (623 vs $320 \mathrm{U} \cdot \mathrm{mL}^{-1}$; $\mathrm{p}<0.01$ ). Median ACT-RC was also lower in this group (fig. 3), but statistical significance was not reached. No differences in the serum level of CRP were found between active and nonactive patients $\left(2.2 v s 3.3 \mathrm{mg} \cdot \mathrm{L}^{-1}\right)$. There were no significant differences in AGP-RC, ACT-RC, AGP, ACT, CRP, ACE, and sIL-2R between the different disease stages (table 2).

In 9 out of 37 patients, increased levels of serum CRP were detected. Compared with patients with normal CRP, elevated serum AGP (1.63 vs $\left.1.10 \mathrm{~g} \cdot \mathrm{L}^{-1} ; \mathrm{p}<0.02\right)$ and increased sIL-2R level (798 vs $\left.344 \mathrm{U} \cdot \mathrm{mL}^{-1} ; \mathrm{p}<0.05\right)$ were found in this group. There were no differences in the median ACE activity (44.0 vs $\left.35.9 \mathrm{U} \cdot \mathrm{L}^{-1}\right)$ and median values of AGP-RC (1.22 vs 1.19) and ACT-RC (3.96 vs 3.36) between the groups.

In the entire sarcoidosis group, regression analysis revealed an inverse linear relationship between ACE

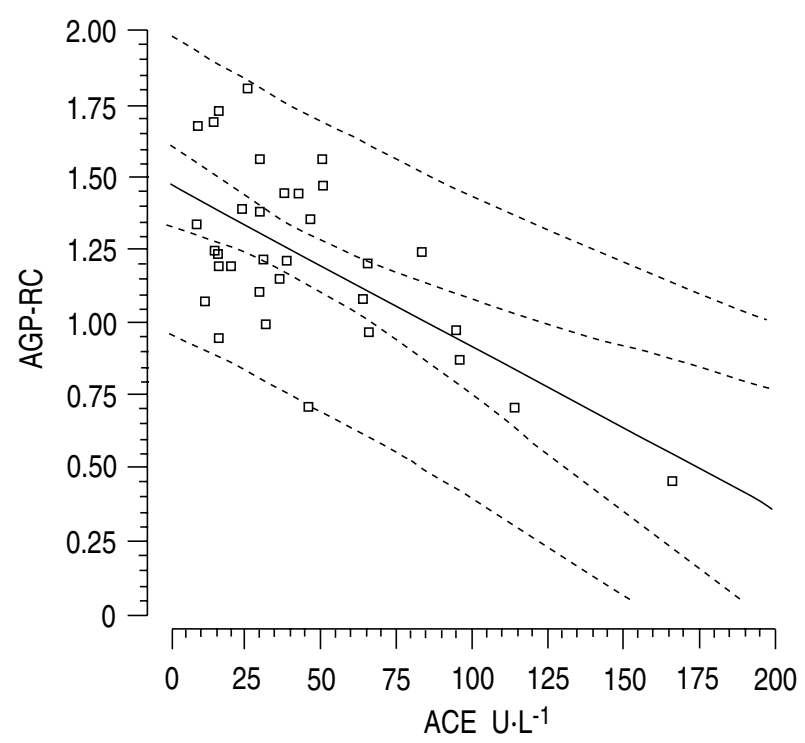

Fig. 4. - Regression curve showing the relationship between $\alpha_{1}$-acid glycoprotein reactivity coefficient (AGP-RC) and serum angiotensinconverting enzyme (ACE) activity (linear model $\mathrm{r}=-0.6358, \mathrm{p}<0.0001$ ). Two pairs of dashed lines closest and farthest to the fitted line present the $95 \%$ confidence and prediction limits, respectively. activity and both AGP-RC ( $\mathrm{r}=-0.6358 ; \mathrm{p}<0.0001)$ (fig. 4) and ACT-RC $(r=-0.5019 ; \mathrm{p}<0.005)$ (fig. 5). There was a correlation between ACE activity and both serum AGP and sIL-2R levels ( $r=0.4501 ; \mathrm{p}<0.01$ and $\mathrm{r}=0.8241$; $\mathrm{p}<0.00001$, respectively). Serum AGP concentration correlated with the sIL-2R concentration $(r=0.5621 ; \mathrm{p}<0.0005)$. There was only a weak association between serum levels of the three acute-phase proteins studied (serum CRP vs serum ACT: $\mathrm{r}=0.4177 ; \mathrm{p}<0.02$; serum AGP $v s$ serum ACT: $r=0.3539 ; \mathrm{p}<0.05)$. AGP-RC and ACT-RC correlated well with each other $(\mathrm{r}=0.8365 ;<0.00001)$.

\section{Discussion}

The results presented here provide evidence that there are changes in the glycosylation pattern of acute-phase glycoproteins in patients with active sarcoidosis. These alterations are characterized by decreased reactivity of acute-phase glycoproteins with conA and indicate an increased serum concentration of glycoforms with conAnonreactive tri- and tetra-antenary heteroglycan sidechains, and decreased concentration of those bearing biantennary carbohydrates. The changes in the glycosylation profile depended to some degree on disease activity;

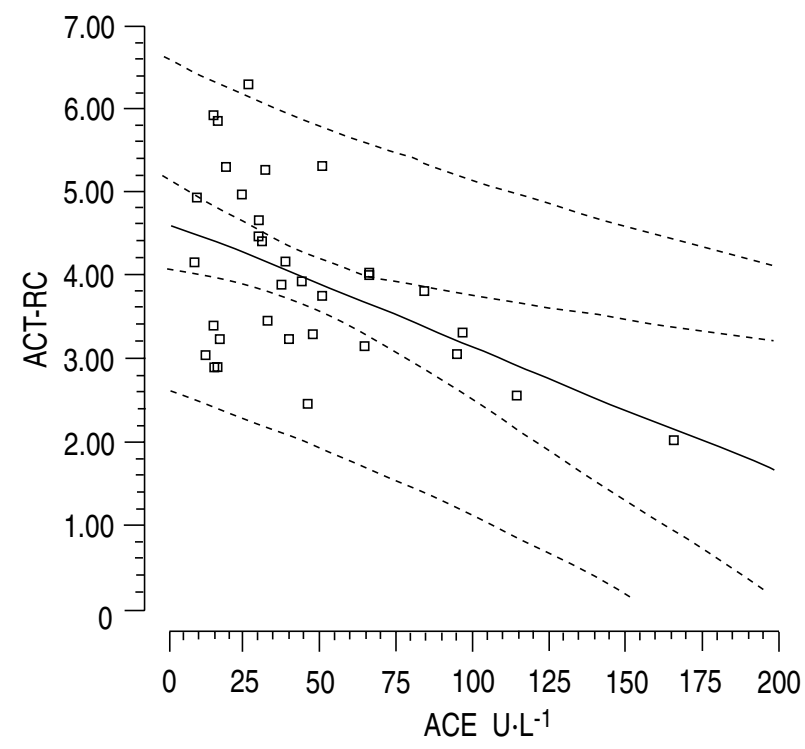

Fig. 5. - Regression curve showing the relationship between $a_{1}$ antichymotrypsin reactivity coefficient (ACT-RC) and serum angiotensinconverting enzyme (ACE) activity (linear model, $r=-0.5019, \mathrm{p}<0.005$ ). Two pairs of dashed lines closest and farthest to the fitted line present the $95 \%$ confidence and prediction limits, respectively. 
patients with active disease had decreased AGP-RC; whereas, normal proportions of various microheterogeneous forms of AGP were detected in those with nonactive disease. There was also a relationship between both AGP-RC and ACT-RC and serum ACE, which is a marker of disease activity in sarcoidosis $[14,16]$.

Cytokines have been shown to induce production of acute-phase proteins in the liver [18-21], and they also regulate their glycosylation [22-27]. Thus, both changes in the serum concentration and in the glycosylation profile of acute-phase proteins should be attributed to the action of cytokines.

From many cytokines studied, only interleukin-6 (IL6) has been demonstrated to induce the synthesis of the full spectrum of human acute-phase proteins including CRP and serum amyloid A (SAA) [18, 19]. A study by DEVERGNE et al. [28] showed that cells expressing IL-1 $\beta$ genes predominated in sarcoid granulomas, whereas those producing interferon- $\gamma(\mathrm{INF}-\gamma)$, tumour necrosis factor$\alpha$ (TNF- $\alpha$ ) interleukin-l $\alpha$ (IL-1 $\alpha$ ), interleukin-2 (IL-2), and IL- 6 were less frequent [28]. The low production of IL-6 in sarcoid lesions would eventually explain normal levels of serum CRP found in most cases.

Many reports confirm the role of IL- $1 \beta$, TNF- $\alpha$, and INF- $\gamma$ in the pathogenesis of sarcoidosis. For instance, it has been demonstrated that alveolar macrophages obtained from patients with sarcoidosis spontaneously released IL- $1 \beta$, TNF- $\alpha$ and INF- $\gamma$ and that this ability correlated with the disease activity [29-33].

The action of IL-1 $\beta$ and/or TNF- $\alpha$ could explain the lack of relationship between the synthesis and glycosylation of acute-phase proteins in patients with sarcoidosis; IL- $1 \beta$ and TNF- $\alpha$ have a moderate effect on the synthesis of some acute-phase proteins, including AGP and ACT although they fail to induce production of CRP or SAA [21]. The same cytokines may affect the glycosylation of acute-phase glycoprotein in hepatocytes $[22,27]$.

In the group studied, serum AGP but neither AGP-RC nor ACT-RC correlated with sIL-2R level. As macrophages present in sarcoid granulomas are a major source of SIL-2R in serum of patients with active sarcoidosis $[34,35]$, the implication is that alterations in the serum concentration of AGP and the changes in the glycosylation profile of this glycoprotein probably reflect different aspects of macrophage activation.

An interesting question is whether the changes in the glycosylation profile of acute-phase glycoproteins might affect their biological activity and/or function. It has been demonstrated by Pos et al. [36] that microheterogeneity variants of AGP differ with regard to their immunomodulatory properties: the conA-nonreactive variant of AGP is more effective in modulation of lymphocyte proliferation than ConA-reactive AGP serum variants. Thus, the increase of serum conA-nonreactive AGP in patients with active sarcoidosis may play a part in the immunopathogenesis of the disease. Recently, it has been shown that AGP has an affinity for E-selectin and that this affinity can be changed by in vitro fucosylation of AGP [37]. As changes in the AGP fucosylation have been found in patients with chronic and acute inflammatory diseases, this mechanism might represent a physiological feedback response on the selectin-mediated interaction between leucocytes and inflamed endothelium. As we focused on the structural changes in the heteroglycan side-chains of AGP, it is difficult to interpret our results in view of the latter data. To our knowledge, there are no reports suggesting that any changes in glycosylation of ACT might influence its function as antiprotease.

Determination of the glycosylation profile of acutephase proteins, especially AGP, may provide a new interesting approach to assessment of the disease activity in sarcoidosis. However, the clinical applicability of this method regarding its sensitivity and specificity needs further evaluation.

\section{References}

1. Hughes RC. Glycoproteins. London, New York, Chapman and Hall, 1984.

2. Schachter H. Glycoproteins: their structure, biosynthesis and possible clinical implications. Clin Biochem 1984; 17: 3-14.

3. Fournet B, Montreuil J, Strecker G, et al. Determination of the primary structures of 16 asialocarbohydrate units derived from human plasma $\alpha-1$-acid glycoprotein by $360 \mathrm{MHz}$ H NMR spectroscopy and permethylation analysis. Biochemistry 1978; 17: 5206-5214.

4. Bierhuizen MFA, De Witt M, Govers CA, et al. Glycosylation of three molecular forms of human $\alpha-1$-acid glycoprotein having different interactions with concanavalin $\mathrm{A}$ : variations in the occurence of di-, tri- and tetraantennary glycans and the degree of sialylation. Eur $J$ Biochem 1988; 175: 387-394.

5. Bøg-Hansen TC. Crossed immuno-affinoelectrophoresis: an analytical method to predict the result of affinity chromatography. Ann Biochem 1973; 56: 480-488.

6. Narasimhan S, Wilson JR, Martin E, Schachter H. A structural basis for four distinct elution profiles on concanavalin A-sepharose affinity chromatography of glycopeptides. Can J Biochem 1978; 57: 83-96.

7. Hansen E, Lithme A, Bøg-Hansen TC. The microheterogeneity components of orosomucoid and the dissociation constants and mobilities of concanavalin A/orosomucoid complexes in crossed affino-immunoelectrophoresis. Electrophoresis 1984; 5: 196-201.

8. Hansen JES, Jensen SP, Norgaard-Pedersen B, BøgHansen TC. Electrophoretic analysis of the glycan microheterogeneity of orosomucoid in cancer and inflammation. Electrophoresis 1986; 7: 180-183.

9. Pawlowski T, Mackiewicz SH, Mackiewicz A. Microheterogeneity of $\alpha$-1-acid glycoprotein in the detection of intercurrent infection in patients with RA. Arthritis Rheum 1989; 32: 347-351.

10. Pawlowski T, Biczysko M, Solarewicz M, Mackiewicz S, Pruchniewski D, Sarrazin O. Microheterogeneity of $\alpha-1$-acid glycoprotein in burns children. In: Freed D, Bøg-Hansen TC, eds. Lectins-biology, biochemistry and clinical biochemistry. St. Louis, Sigma Press, 1988; 6: pp. 491-496.

11. Mackiewicz A, Pawlowski T. Major microheterogeneity of $\alpha-1$-acid glycoprotein in rheumatic diseases. In: Bauman $\mathrm{P}$, et al. eds. Genetics, biochemistry, physiological functions and pharmacology of $\alpha$-1-acid glycoprotein. New York, Allan R. Liss Inc., 1989; pp. 219-222. 
12. Mackiewicz A, Khan MA, Reynolds TL, van der Linden S, Kushner I. Serum IgA, acute phase proteins and glycosylation of $\alpha_{-1}$-acid glycoprotein in ankylosing spondylitis. Ann Rheum Dis 1989; 48: 99-103.

13. Hind CR, Flint KC, Hudspith BN, Felmingham D, Brostoff J, Johnson NM. Serum C-reactive protein concentrations in patients with pulmonary sarcoidosis. Thorax 1987; 42: 332-335.

14. Beneteau-Burnat B, Baudin B. Angiotensin-converting enzyme: clinical applications and laboratory investigations on serum and other biological fluids. Crit Rev Clin Lab Sci 1991; 28: 337-356.

15. Allen RK. A review of angiotensin converting enzyme in health and disease. Sarcoidosis 1991; 8: 95-100.

16. Keicho N, Kitamura K, Takaku F, Yotsumoto H. Serum concentration of soluble interleukin-2 receptor as a sensitive parameter of disease activity in sarcoidosis. Chest 1990, 98: 1125-1129.

17. Laurell CB. Quantitative estimation of proteins by electrophoresis in agarose gel containing antibodies. Anal Biochem 1966; 15: 45-52.

18. Castell JV, Gomez-Lechon MJ, David M, et al. Interleukin6 is the major regulator of acute phase protein synthesis in adult human hepatocytes. FEBS Lett 1989; 242: 237-239.

19. Hirano T. The biology of interleukin-6. Chem Immunol 1992; 51: 153-180.

20. Ramadori G, Van Damme J, Rieder H, Meyer zum Buschenfelde KH. Interleukin-6, the third mediator of acute-phase reaction, modulates hepatic protein synthesis in human and mouse. Comparison with interleukin $-1 \beta$ and tumor necrosis factor- $\alpha$. Eur J Immunol 1988; 18: $1259-1264$.

21. Andus T, Geiger T, Hirano T, Kishimoto T, Heinrich PC. Action of recombinant human interleukin-6, interleukin- $1 \beta$ and tumor necrosis factor- $\alpha$ on the mRNA induction of acute-phase proteins. Eur J Immunol 1988; 18: 739-746.

22. Mackiewicz A, Ganapathi MK, Schultz D, Kushner I. Monokines regulate glycosylation of acute phase proteins. J Exp Med 1987; 166: 253-258.

23. Mackiewicz A, Schultz D, Mathison J, Ganapathi M, Kushner I. Effect of cytokines on glycosylation of acute phase proteins in human hepatoma cell lines. Clin Exp Immunol 1989; 74: 70-75.

24. Mackiewicz A, Kushner I. Interferon- $\beta_{2} / \mathrm{B}$-cell stimulating factor $2 /$ interleukin- 6 affects glycosylation of acute phase proteins in human hepatoma cell lines. Scand $J$ Immunol 1989; 29: 265-271.

25. Mackiewicz A, Kushner I. Transforming growth factor$\beta_{1}$ influences glycosylation of $\alpha$-1-protease inhibitor in human hepatoma cell lines. Inflammation 1990; 14: 485-497.
26. Pos O, van der Stelt ME, Wolbink GJ, Nijsten MW, van der Tempel GL, van Dijk W. Changes in the serum concentration and the glycosylation of human $\alpha$-1-acid glycoprotein and $\alpha$-1-protease inhibitor in severely burned persons: relation to interleukin-6 levels. Clin Exp Immunol 1990; 82: 579-582.

27. Pous C, Chauvelot-Moachon L, Lecoustillier M, Durand G. Recombinant human interleukin- $1 \beta$ and tumor necrosis factor affect glycosylation of serum $\alpha$-1-acid glycoprotein in rats. Inflammation 1992; 16: 197-203.

28. Devergne O, Emilie D, Peuchmaur M, Crevon MC, D'Agay MF, Galanaud P. Production of cytokines in sarcoid Iymph nodes: preferential expression of interleukin- $1 \beta$ and interferon- $\gamma$ genes. Hum Pathol 1992; 23 : 317-323.

29. Strausz J, Mannel DN, Pfeifer S, Borkowski A, Ferlinz R, Müller-Quernheim J. Spontaneous monokine release by alveolar macrophages in chronic sarcoidosis. Int Arch Allergy Appl Immunol 1991; 96: 68-75.

30. Barth J, Kreipe H, Radzun HJ, Petermann W. Interleukin1-Sekretion aus Alveolarmakrophagen bei pulmonaler Sarkoidose. Pneumologie 1990; 44(Suppl. 1): 215-216.

31. Baughman RP, Strohofer SA, Buchsbaum J, Lower EE. Release of tumor necrosis factor by alveolar macrophages of patients with sarcoidosis. J Lab Clin Med 1990; 115: 36-42.

32. Bachwich PR, Lynch JP III, Larrick J, Spengler M, Kunkel SL. Tumor necrosis factor production by human sarcoid alveolar macrophages. Am J Pathol 1986; 125: 421425.

33. Eden E, Turino GM. Interleukin-1 secretion from human alveolar macrophages in lung disease. J Clin Immunol 1986; 6: 326-333.

34. Hancock WW, Muller WA, Cotran RS. Interleukin-2 receptors are expressed by alveolar macrophages during pulmonary sarcoidosis and are inducible by lymphokine treatment of normal human lung macrophages, blood monocytes and monocyte cell lines. J Immunol 1987; 138: $185-191$.

35. Ina Y, Takada K, Sato T, Yamamoto M, Noda M, Morishita M. Soluble interleukin-2 receptors in patients with sarcoidosis: possible origin. Chest 1992; 102: 1128-1133.

36. Pos O, Oostendorp RA, van der Stelt ME, Scheper RJ, van Dijk W. Con A-nonreactive human $\alpha$-1-acid glycoprotein (AGP) is more effective in modulation of lymphocyte proliferation than con A-reactive AGP serum variants. Inflammation 1990; 14: 133-141.

37. De Graaf TW, van der Stelt ME, Anbergen MG, van Dijk W. Inflammation-induced expression of sialyl Lewis $\mathrm{X}$-containing glycan structures on $\alpha$-1-acid glycoprotein (orosomucoid) in human sera. J Exp Med 1993; 177: 657-666. 